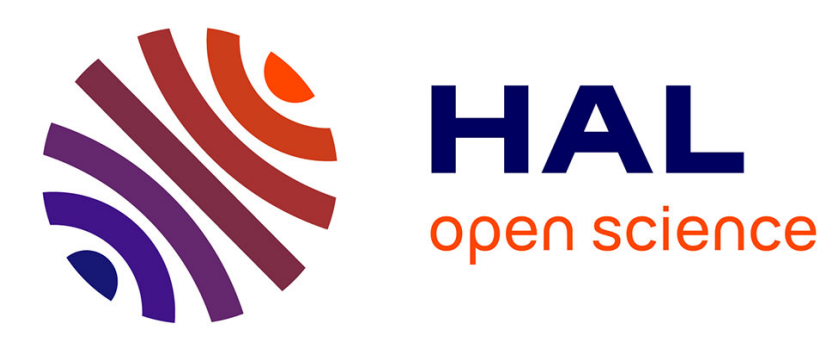

\title{
Urethanes synthesis from oxamic acids under electrochemical conditions
}

\author{
Ikechukwu Martin Ogbu, Jonathan Lusseau, Gülbin Kurtay, Frédéric Robert, \\ Yannick Landais
}

\section{> To cite this version:}

Ikechukwu Martin Ogbu, Jonathan Lusseau, Gülbin Kurtay, Frédéric Robert, Yannick Landais. Urethanes synthesis from oxamic acids under electrochemical conditions. Chemical Communications, 2020, 56 (81), pp.12226-12229. 10.1039/d0cc05069e . hal-02988402

\section{HAL Id: hal-02988402 \\ https://hal.science/hal-02988402}

Submitted on 13 Nov 2020

HAL is a multi-disciplinary open access archive for the deposit and dissemination of scientific research documents, whether they are published or not. The documents may come from teaching and research institutions in France or abroad, or from public or private research centers.
L'archive ouverte pluridisciplinaire HAL, est destinée au dépôt et à la diffusion de documents scientifiques de niveau recherche, publiés ou non, émanant des établissements d'enseignement et de recherche français ou étrangers, des laboratoires publics ou privés. 


\section{Urethanes synthesis from oxamic acids under electrochemical conditions}

Ikechukwu Martin Ogbu, Jonathan Lusseau, Gülbin Kurtay, Frédéric Robert, and Yannick Landais*

University of Bordeaux, Institute of Molecular sciences (ISM), UMR-CNRS 5255, 351, Cours de la Libération, 33405

Talence Cedex, France.

E-mail : yannick.landais@u-bordeaux.fr

Urethanes synthesis via oxidative decarboxylation of oxamic acids under mild electrochemical conditions is reported. This simple phosgene-free route to urethanes involves an in-situ generation of isocyanates by anodic oxidation of oxamic acids in an alcoholic medium. The reaction is applicable to a wide range of oxamic acids, including chiral ones, and alcohols furnishing the desired urethanes in a one-pot process without the use of a chemical oxidant.

The urethane (or carbamates) functional group is present in a large number of substrates of pharmaceutical and agrochemical interest. ${ }^{1}$ Urethanes exhibit excellent proteolytic stabilities ${ }^{2}$ and are consequently used frequently as a peptide bond surrogate. ${ }^{3}$ Carbamates have been popularized in organic synthesis as amine protecting groups, ${ }^{4}$ showing convenient orthogonality and stability towards acids, bases or reducing conditions depending on the nature of the substituent. The addition of alcohols to isocyanates is likely one of the most reliable method to access urethanes, but also polyurethanes (Bayer reaction). ${ }^{5}$ However, the known isocyanates carcinogenicity and the synthesis of the latter from toxic phosgene constitute a major limit to the use of this reaction. Isocyanates may also be conveniently accessed from parent oxamic acids. The latter have emerged as versatile synthons for the synthesis of amide-containing organic compounds. ${ }^{6}$ Oxamic acids are stables ${ }^{7}$ and easily accessible through the coupling between amines and oxalic acid derivatives. ${ }^{8}$ Minisci and co-workers originally showed that oxamic acids are useful precursors of isocyanates. ${ }^{9}$ This approach involved the use of ammonium persulfate as an oxidant in the presence of $\mathrm{Ag}(\mathrm{I})$ and $\mathrm{Cu}(\mathrm{II})$ salts as catalysts to achieve oxidative decarboxylation of oxamic acid into isocyanate (Figure 1a). However, the reaction performed in a two-phase medium $\left(\mathrm{H}_{2} \mathrm{O}-\mathrm{CH}_{2} \mathrm{Cl}_{2}\right)$ did not allow for a direct access to urethane without isolation of the carcinogenic isocyanate and led to the latter with moderate yields. Leveraging this, we recently showed that urethanes can be accessed through a one-pot metal-free visible light-mediated oxamic acids decarboxylation, thereby generating isocyanates in-situ, which in the presence of an alcohols furnished urethanes in good to excellent yields (Figure 1b). ${ }^{8 a}$ This strategy involved the use of an organophotocatalyst and hypervalent iodine (III) as an oxidant to trigger the free-radical conversion of oxamic acids into isocyanates.

(a) Minisci synthesis of isocyanates from oxamic acids (Ref. 9)

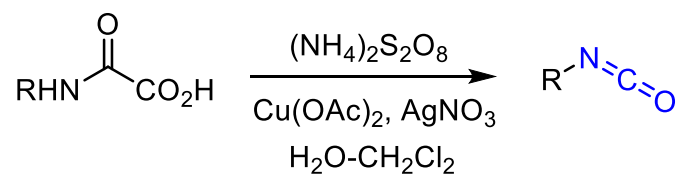

(b) Urethanes from oxamic acids using visible light/hypervalent iodine oxidation (Ref. 8a)

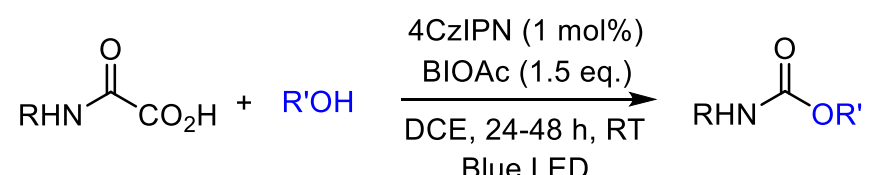

(c) Urethanes through electrochemical decarboxylation of oxamic acids (this work)

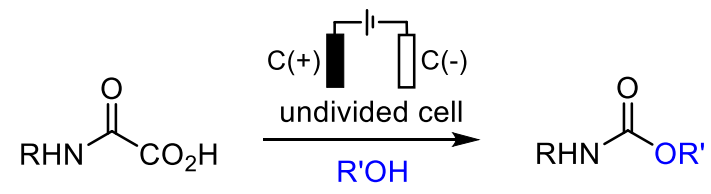

Figure 1 Oxamic acids as green precursors of urethanes 
Encouraged by these results, we sought to simplify further this useful process, designing a metal-, photocatalyst, light- and oxidant-free route relying on electrochemistry to mediate single electron transfers during the oxamic acid decarboxylation. There is an increasing interest in the use of simple electrochemical set-up in organic synthesis due to its simplicity, promising environmental benefits and sustainability, limiting the recourse to expensive chemicals and minimizing waste. ${ }^{10}$ We thus report herein a practical urethane synthesis via a mild anodic oxidation of oxamic acids.

The process was first optimized, as summarized in Table 1, using oxamic acid 1a as a model compound, and $\mathrm{MeOH} 2 \mathrm{a}$, both as a solvent and a nucleophile, to trap the isocyanate generated in situ. Unless indicated, graphite electrodes were used both as cathode and anode. The reaction was first conducted under basic conditions using triethylamine (TEA), and a constant current of $60 \mathrm{~mA}$ was applied. ${ }^{11}$ Gratifyingly, the corresponding methyl carbamate $3 a$ was obtained in $72 \%$ yield along with $20 \%$ of 1,1-diethyl-3-phenethylurea as a result of the amine oxidation $^{12}$ (see 8, vide infra) (Table 1, entry 1). Decreasing the amount of the base to 0.1 eq resulted in a slight increase in yield (entry 2) and the absence of urea. Replacement of TEA with other bases including ammonia, or guanidines such as TBD or MTBD did not help improving the yield of $\mathbf{3 a}$ (entries 3-5). The reaction time was equally extended to $8 \mathrm{~h}$, but no significant effect was observed on the yield (entry 6). Furthermore, when the current was lowered to $5 \mathrm{~mA}$ and reaction time increased up to $12 \mathrm{~h}$, conversion into $3 \mathrm{a}$ reached $80 \%$ (entry 7 ). Interestingly, the reaction worked also well in the absence of a base, 3a being isolated in $77 \%$ ( $84 \%$ conversion) without any additives (entry 8 ). Under these conditions, the reaction time was further extended to $18 \mathrm{~h}$, without yield improvement (entry 9). The role of a supporting electrolyte was also studied, showing that tetrabutylammonium perchlorate $\left(n-\mathrm{Bu}_{4} \mathrm{NClO}_{4}\right)^{11 \mathrm{~b}}$ did not bring any improvement (entry 10$)$, while $n$ - $\mathrm{Bu}_{4} \mathrm{NI}$ led to a drastic decrease in yield, possibly as a result of its competitive decomposition at the anode (entry 11). ${ }^{13}$ Finally, the nature of electrodes was investigated. The use of a platinum anode significantly decreased the yield (entry 12), while stainless steel did not provide the product at all (entry 13). Nickel foam exhibited a similar performance as graphite anode (entry 14), in good agreement with literature precedent, showing that graphite and nickel anodes favour Hofer-Moest type reactions, as multi-electron transfer is improved due to a better absorption on foam as compared to metallic surface. ${ }^{11 b, 14}$ The reaction was finally performed in air with success, indicating that the process could proceed appreciably without much precautions to exclude air (entry 15).

Under these optimal conditions (entry 8), substrate scope was extended by varying the nature of oxamic acids in the presence of $\mathrm{MeOH}$ 2a as a nucleophile and solvent (Scheme 1). These conditions thus allowed the conversion of a wide range of oxamic acids $\mathbf{1 a - m}$, furnishing methyl carbamates 3a-m in moderate to high yield (Scheme 1). These mild conditions were found compatible with arenes bearing electron-withdrawing (3b, 3e-f) or electrondonating (3c) substituents. Interestingly, while oxamic acids having benzylic substituents (1) $\mathbf{b}-\mathbf{c}, \mathbf{1} \mathbf{e}-\mathbf{h}$ ) were shown to be sensitive to oxidation, using our previous photocatalytic conditions, ${ }^{8 a}$ the corresponding urethanes were obtained in good yields under electrochemical conditions. Bis-oxamic acids $\mathbf{1} \mathbf{k}-\mathbf{m}$ were also shown to undergo the reaction, resulting in the corresponding bis(methyl carbamates) $\mathbf{3 k - m}$ in satisfying yields. In this case, supporting electrolyte was used in small quantities as it was shown to improve conductivity and conversion.<smiles>O=C(O)C(=O)NCCc1ccccc1</smiles>

$1 \mathrm{a}$

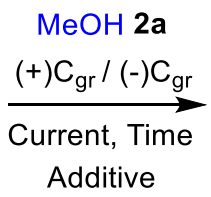

Additive<smiles>COC(=O)NCCc1ccccc1</smiles>

3a

Table 1 Electrochemical conversion of oxamic acid 1a into urethane $3 a$. 


\begin{tabular}{lcccc}
\hline entry $^{\mathrm{a}}$ & Current (mA) & Additive (eq.) & Time (h) & Yield (\%) $^{\mathrm{b}}$ \\
\hline 1 & 60 & $\mathrm{TEA}(1.0)$ & 5 & 72 \\
2 & 60 & $\mathrm{TEA}(0.1)$ & 5 & $78(72)$ \\
3 & 60 & $\mathrm{NH}_{3}(0.1)$ & 5 & 76 \\
4 & 60 & $\mathrm{TBD}(0.1)$ & 5 & 70 \\
5 & 60 & $\mathrm{MTBD}(0.1)$ & 5 & 68 \\
6 & 60 & $\mathrm{TEA}(0.1)$ & 8 & 79 \\
7 & 5 & $\mathrm{TEA}(0.1)$ & 12 & 80 \\
8 & 5 & - & 12 & $84(77)$ \\
9 & 5 & - & 18 & 84 \\
10 & 5 & $n-\mathrm{Bu}_{4} \mathrm{NClO}_{4}(0.1)$ & 12 & 83 \\
11 & 5 & $n-\mathrm{Bu}_{4} \mathrm{NI}^{(0.1)}$ & 12 & 26 \\
$12^{\mathrm{c}}$ & 5 & - & 12 & 40 \\
$13^{\mathrm{d}}$ & 5 & - & 12 & $\mathrm{ND}$ \\
$14^{\mathrm{e}}$ & 5 & - & 12 & 83 \\
$15^{\mathrm{f}}$ & 5 & - & 12 & 84
\end{tabular}

${ }^{a}$ Unless otherwise mentioned, all reactions were performed with 1a $(0.5 \mathrm{mmol}), \mathbf{2 a}(3 \mathrm{~mL})$, graphite anode and cathode, under argon atmosphere unless indicated, in an ElectraSyn vial, undivided cell at room temperature. ${ }^{b}$ Yields of 3a determined by ${ }^{1} \mathrm{H}$ NMR with 1,3,5- trimethylbenzene as an external standard (Isolated yields of $\mathbf{3 a}$ under brackets). ${ }^{\mathrm{c}}$ Platinum anode. ${ }^{\mathrm{d}}$ Stainless steel anode. ${ }^{\mathrm{e}}$ Nickel anode. ${ }^{\mathrm{f}}$ Reaction in air.
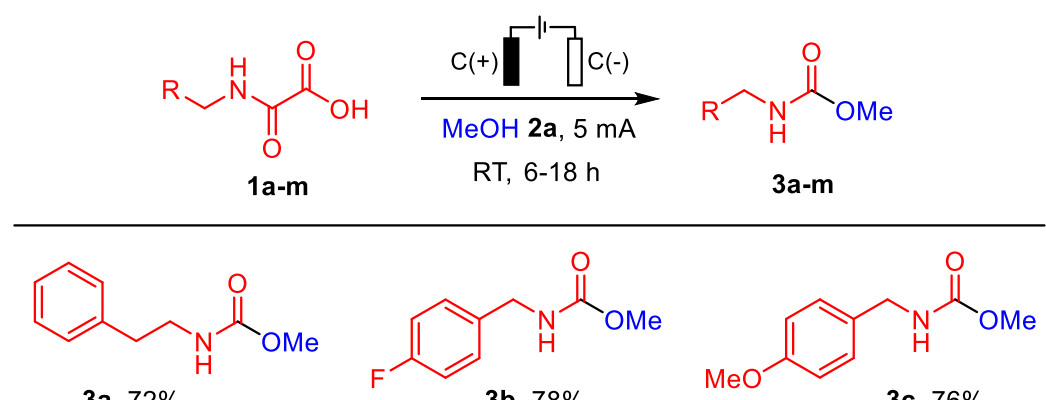

3a, $72 \%$

3b, $78 \%$

3c, $76 \%$<smiles>COC(=O)NC(C)(C)c1ccccc1</smiles>

$3 d, 53 \%$<smiles>COC(=O)NCc1cccs1</smiles>

3g, $41 \%$<smiles>COC(=O)NC(C)c1ccccc1</smiles>

3j, $70 \%$<smiles>COC(=O)NCC1CCC(CNC(=O)OC)CC1</smiles><smiles>COC(=O)NCc1ccc(Cl)cc1</smiles>

3f, $68 \%$

$3 i, 73 \%$

$$
\text { 3h, } 70 \%
$$<smiles>COC(=O)NCCCCCCNC(=O)OC</smiles>

$3 k, 50 \%$<smiles>COC(=O)NCc1ccc(CNC(=O)OC)cc1</smiles>

Scheme 1 Electrochemical decarboxylation of oxamic acids in the presence of $\mathrm{MeOH} 2 \mathrm{a}$. Oxamic acid scope. ${ }^{\text {a }}$ $\left(n-\mathrm{Bu}_{4}\right) \mathrm{NClO}_{4}$ (0.1 eq.) was added. 
Other alcohols $\mathbf{2} \mathbf{b}-\mathbf{I}$ were then submitted to the optimal reaction conditions above. Although alcohols with higher molecular weight than $\mathrm{MeOH} 2 \mathrm{2a}$ display lower electrical conductivity, ${ }^{15}$ they were shown to be competent solvents and nucleophiles in the presence of a supporting electrolyte, affording the desired urethanes in moderate to good yields (Scheme 2).



Scheme 2 Electrochemical decarboxylation of oxamic acids in the presence of alcohols $\mathbf{2 b - I}$. Alcohol scope. ${ }^{\mathrm{a}}$ room temperature.

Improved yields were obtained by heating up the electrochemical cell during electrolysis. Beside a known enhanced reactivity of alcohols towards isocyanates with increasing temperature, ${ }^{5 a}$ the mild heating increases the conductivity of the medium, ${ }^{15}$ and also likely improves the solubility and mass transport of ions to the electrodes. ${ }^{16}$ The reaction conditions are compatible with alcohols bearing a $\mathrm{Cl}(\mathbf{4 i}, \mathbf{4 m})$, ethers $(\mathbf{4 r}-\mathbf{u})$ and $\mathrm{CF}_{3}$ groups $(\mathbf{4 c}, \mathbf{4 g})$ as well as a double bond $(\mathbf{4 h}, \mathbf{4 n})$. The reaction was equally shown to work appreciably well in a one gram-scale experiment, furnishing the product $4 \mathrm{a}$ in $61 \%$. Double addition was also observed with bis-oxamic acids leading to the corresponding bis-urethanes $\mathbf{4 v - w}$ in reasonable yields. Some limitations were however noticed during this study. For instance, oxamic acids derived from anilines were not successful under these conditions, as already observed using the photocatalyzed process, ${ }^{8 a}$ due to the competitive decarbonylation of the putative carbamoyl radical intermediate (vide infra). ${ }^{9 b}$ Degradation was also observed using benzyl alcohol (oxidation) or 2-bromoethanol, which led instead to the ester of the oxamic acid (ESI). It is worth noticing that although the alcohol is used as a solvent, vacuum distillation at the end of the process was successful, allowing about $90 \%$ alcohol recovery with satisfying purity $\left({ }^{1} \mathrm{H}\right.$ NMR). 
Finally, chiral oxamic acids 5a-c derived from the corresponding (L)-amino acids, ${ }^{8 b}$ were also submitted to the above electrochemical conditions (Scheme 3), leading to the expected urethanes 6a-i in satisfying yields without racemization, as shown by chiral HPLC on racemic and homochiral $\mathbf{6 f}$ (ESI).<smiles>[R]C(NC(=O)C(=O)O)C(=O)OC</smiles><smiles>CCOC(=O)C[C@@H](CC(=O)OCC(=O)c1ccccc1)NC(=O)OCC</smiles>

6a, $51 \%$ 2b-f

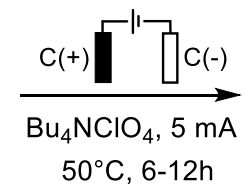

$50^{\circ} \mathrm{C}, 6-12 \mathrm{~h}$<smiles>[R]OC(=O)NC([R])C(=O)OC</smiles>

6a-i<smiles>C=CCOC(=O)N[C@@H](CC(C)=O)C(C)=O</smiles>

6d, $41 \%$<smiles>CCOC(=O)NC(CC)C(=O)OC</smiles>

6b, $50 \%$<smiles>C=CCOC(=O)N[C@@H](C)C(=O)OC</smiles>

6c, $61 \%$<smiles>COC(=O)C[C@H](NC(C)=O)C(C)=O</smiles>

$6 \mathrm{~g}, 78 \%$<smiles>COC(=O)NC(Cc1ccccc1)C(=O)OC</smiles><smiles>CCOC(=O)N[C@@H](Cc1ccccc1)C(=O)OC</smiles>

6f, $65 \%$<smiles>COC(=O)[C@H](Cc1ccccc1)NC(=O)OCC(F)(F)F</smiles>

Scheme 3 Electrochemical decarboxylation of amino-acids derived oxamic acids in the presence of alcohols $\mathbf{2 b} \mathbf{b} \mathbf{c}$.

A tentative mechanism for the electrochemical decarboxylation of oxamic acids is finally proposed, as depicted in Figure 2. Oxidation of oxamic acid $\mathbf{A}$ at the anode should generate a ketocarboxyl radical $\mathbf{I}$, which would then suffer decarboxylation leading to the carbamoyl radical II. ${ }^{17} \mathrm{~A}$ second oxidation event would then convert II into the carbamoyl cation III (that may also be written as a protonated isocyanate IV), the reaction of which with alcohol $\mathbf{B}$ furnishing the urethane $\mathbf{C}$ along with one proton. Reduction of $\mathrm{H}^{+}$at the cathode produces in turn hydrogen.

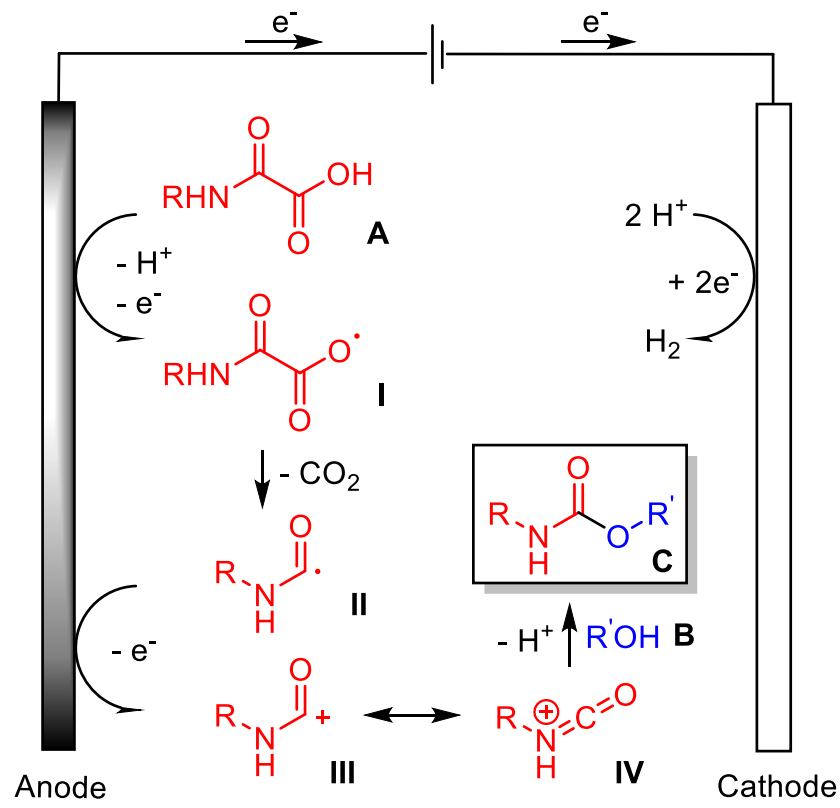

Figure 2 Mechanism of the electrochemical decarboxylation of oxamic acids. 
The formation of the intermediate carbamoyl radical is supported by the formation of diamide 7 during electrolysis of oxamic acid $\mathbf{1}$ in the presence of $\mathrm{MeOH} \mathbf{2 a}$ in $\mathrm{CH}_{2} \mathrm{Cl}_{2}$ (Scheme 4). The presence of the coupling product $\mathbf{7}$ also suggests that the oxidation of radical II into III is a slow process, in good agreement with Minisci's observations. ${ }^{9}$ As mentioned above, when TEA was used as a base, competing oxidation of the amine occurs, which is in line with the oxidative potential of $\mathrm{NEt}_{3}$ and oxamic acids respectively of $+0.95 \mathrm{~V}^{18}$ and $+1.17 \mathrm{~V}^{6 \mathrm{~g}}$ (Vs $\mathrm{SCE}$ ). Electrochemical oxidation of $\mathrm{Et}_{3} \mathrm{~N}$ is known to lead, in the presence of traces of water, to formaldehyde and diethylamine ${ }^{12}$ the latter then adding to carbamoyl cation IV to afford $\mathbf{8}$, thus supporting the formation of IV as an intermediate.
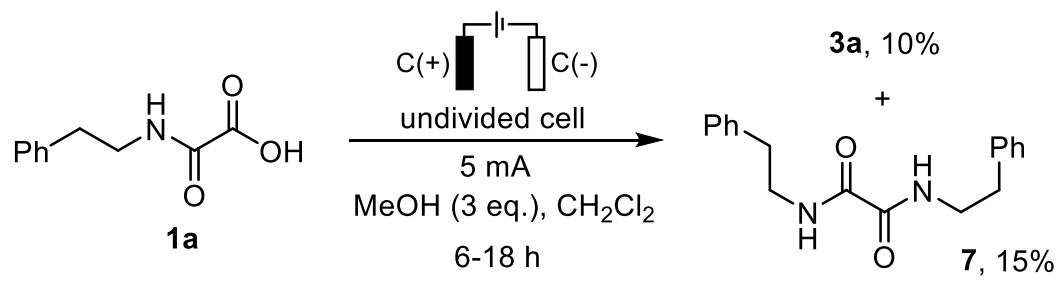<smiles>O=C(O)C(=O)NCCc1ccccc1</smiles>

$1 \mathrm{a}$

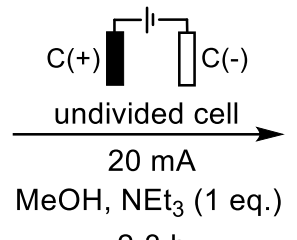

$2-3 \mathrm{~h}$

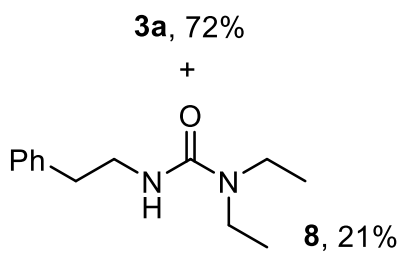

Scheme 4 Mechanistic studies supporting the formation of carbamoyl radical II and cation III-IV.

In summary, we reported the preparation of urethanes from oxamic acids and alcohols through a practically simple electrochemical process. The method allows the formation of various urethanes in moderate to good yields without isolation of the carcinogenic isocyanates generated in situ and directly trapped by alcohols. This metal-, photocatalyst-, light- and oxidant-free reaction proceeds under mild conditions and should serve as a useful tool to access these important targets of pharmaceutical interest.

\section{References}

1 (a) A. K. Ghosh, and M. Brindisi, J. Med. Chem., 2015, 58, 2895; (b) D. Chaturvedi, Tetrahedron, 2012, 68, 15.

2 (a) F. Vacondio, C. Silva, M. Mor, and B. Testa, Drug Metab. Rev., 2010, 42, 551; (b) B. Testa, and J. M. Mayer, Hydrolysis in Drug and Prodrug Metabolism - Chemistry, Biochemistry, and Enzymology; WileyVCH: Weinheim, Germany, 2003.

3 C. Y. Cho, E. J. Moran, S. R. Cherry, J. C. Stephans, S. P. Fodor, C. L. Adams, A. Sundaram, J. W. Jacobs, and P. G. Shultz, Science, 1993, 261, 1303.

4 T. W. Greene, and P. G. M. Wuts, Protecting Groups in Organic Synthesis, $3^{\text {rd }}$ Ed. J. Wiley \& Sons, New York, (1999), 503.

5 (a) S. Ozaki, Chem. Rev., 1972, 72, 457; (b) O. Bayer, Angew. Chem., 1947, 59, 257.

6 (a) M. Li, C. Wang, P. Fang, and H. Ge, Chem. Commun., 2011, 47, 6587; (b) M. Yuan, L. Chen, J. Wang, S. Chen, K. Wang, Y. Xue, G. Yao, Z. Luo, and Y. Zhang, Org. Lett., 2015, 17, 346; (c) W. F. Petersen, R. J. K. Taylor, and J. R. Donald, Org. Biomol. Chem., 2017, 15, 5831; (d) Q.-F. Bai, C. Jin, J.-Y. He, and G. Feng, Org. Lett., 2018, 20, 2172; (e) M. Jouffroy, and J. Kong, Chem. Eur. J., 2019, 25, 2217; (f) M. T. Westwood, C. J. C. Lamb, D. R. Sutherland, and A.-L. Lee, Org. Lett., 2019, 21, 7119; (g) X.-L. Lai, X.-M. Shu, J. Song, and H.-C. Xu, Angew. Chem. Int. Ed., 2020, 59, 10626; (h) J.-W. Yuan, Q. Chen, C. Li, J.-L. Zhu, L.-R. Yang, S.-R. Zhang, P. Mao, Y.-M. Xiao, and L.-B. Qu, Org. Biomol. Chem., 2020, 18, 2747.

7 J.-W. Yuan, J.-L. Zhu, H.-L. Zhu, F. Peng, L.-Y. Yang, P. Mao, S.-R. Zhang, Y.-C. Lib, and L.-B. Quc, Org. Chem. Front., 2020, 7, 273.

8 (a) G. G. Pawar, F. Robert, E. Grau, H. Cramail, and Y. Landais, Chem. Commun., 2018, 54, 9337; (b). A. H. Jatoi, G. G. Pawar, F. Robert, and Y. Landais, Chem. Commun., 2019, 55, 466. 
9 (a) F. Minisci, F. Coppa, and F. Fontana, J. Chem. Soc., Chem. Commun., 1994, 679; (b) F. Minisci, F. Fontana, F. Coppa, and Y. M. Yan, J. Org. Chem., 1995, 60, 5430.

10 (a) Organic Electrochemistry, Ed. H. Lund, O. Hammerich, Marcel Dekker Inc. New-York, 1991, $4^{\text {th }}$ ed.; (b) Y. Jiang, K. Xu, and C. Zeng, Chem. Rev., 2018, 118, 4485; (c) D. Pollok, and S. R. Waldvogel, Chem. Sci., 2020, DOI: 10.1039/x0xx00000x; (d) C. Schotten, T. P. Nicholls, R. A. Bourne, N. Kapur, B. N. Nguyen, and C. E. Willans, Green Chem., 2020, DOI: 10.1039/d0gc01247e;

11 (a) X. Ma, X. Luo, S. Dochain, C. Mathot, and I. E. Markò., Org. Lett., 2015, 17, 4690; (b) G. Beutner, M. R. Collins, A. Davies, M. D. Bel, G. M. Gallego, J. E. Spangler, J. Starr, S. Yang, D. G. Blackmond, and P. S. Baran., Nature 2019, 573, 398.

12 M. Masui, H. Sayo, and Y. Tsuda, J. Chem. Soc. B, 1968, 973.

$13 \mathrm{~K}$. Hu, Y. Zhang, Z. Zhou, Y. Yang, Z. Zha, and Z. Wang, Org. Lett., 2020, 22, ASAP, DOI: 10.1021/acs.orglett.0c01821.

14 (a) S. D. Ross, and M. Finkelstein, J. Org. Chem., 1969, 34, 2923; (b) A. D. Garcia, M. C. Leech, A. Petti, C. Denis, I. C. A. Goodall, A. P. Dobbs, and K. Lam, Org. Lett., 2020, 22, DOI: 10.1021/acs.orglett.0c01324; (c) Z. Wang, Hofer-Moest Reaction, Comprehensive Organic Name Reactions and Reagents, J. Wiley \& Sons. Inc., 2010, 1443.

15 M. Prego, O. Cabeza, E. Carballo, C. F. Franjo, and E. Jimenez, J. Mol. Liq., 2000, 89, 233.

16 C. Reichardt, Solvents and Solvent Effects in Organic Chemistry, Wiley-VCH: Weinheim, Germany, 2003, $3^{\text {rd }} \mathrm{Ed}$.

17 (a) C. Chatgilialoglu, D. Crich, M. Komatsu, and I. Ryu, Chem. Rev. 1999, 99, 1991; (b) G. B. Gill, G. Pattenden and S. J. Reynolds, J. Chem. Soc., Perkin Trans. 1, 1994, 369.

18. (a) D. Badocco, F. Zanon, and P. Pastore, Electrochem. Acta, 2006, 51, 6442; (b) F. Kanoufi, Y. Zu, and A. J. Bard, J. Phys. Chem. B, 2001, 105, 210; (c) R. F. Dapo, C. K. Mann, Anal. Chem. 1963, 35, 677. 